\title{
Antiplatelet and antibacterial activities of Essential Oils obtained from rhizomes and leaves of Hedychium coronarium J. Koening
}

\author{
LUIS GUZMÁN, LUZ S. NERIO, WHITNEY VENTURINI, JULYLETH P.J. MACIAS, WENDY \\ DONOSO \& OSCAR FORERO-DORIA
}

\begin{abstract}
Hedychium coronarium J. Koening, belonging to Zingiberaceae family, is a perennial herb with fleshly aromatic rhizomes. There are no information about the antiplatelet properties of essential oils (EOs) from rhizomes (HCR) and leaves (HCL) of this herb, additionally, there are reports about the antibacterial activity of the Zingiberaceae species, however, no studies have been carried out in the Colombian Amazon Region. The EOs were characterized by GC-MS, the antiaggregant activity was assessed by ADP and Collagen as platelet agonist and the antibacterial activity against E. faecalis and S. aureus were evidenced by the determination of minimum inhibitory concentration (MIC) and minimum bactericidal concentration (MBC). A high content of oxygenated monoterpenes were found in HCL essential oil (EO) and 20 compounds were identified in HCR EO. The HCL EO showed antiaggregant activity when collagen was used and HCR EO showed a concentration-dependent activity against ADP and collagen, meanwhile only the HCR EO showed antibacterial activity against E. faecalis and S. aureus.
\end{abstract}

Key words: Hedychium coronarium J. Koening, antiaggregant property, antibacterial, essential oil.

\section{INTRODUCTION}

Herbs and spices have been widely used for generations as food ingredients and for treating ailments; nowadays, scientific information demonstrate that these natural products contain essential oils (EOS) with different properties used in the prevention and treatment of diseases. Continual research motivated by the increasing incidence of cardiovascular and infectious diseases have recognized in different herbal species, an important source of compounds with antiplatelet and antibacterial properties (Tognolini et al. 2006, El Haouari \& Rosado 2016, Vieitez et al. 2018).

Hedychium coronarium J. Koening, belonging to Zingiberaceae family, is a perennial herb growing to a height of 0.5 - $1.5 \mathrm{~m}$ tall, with fleshly aromatic rhizomes. It is used worldwide, as food flavoring and seasoning (Prakash et al. 2010), but also in traditional medicine for treatment of diabetes, diphtheria, fever, headache, rheumatism and cancer (Bhandary et al. 1995, Matsuda et al. 2002, Oh et al. 2006, Kunnumakkara et al. 2008); its EOs has antioxidant, antimicrobial, anti-inflammatory and mosquito larvicidal properties (Prakash et al. 2010, Noriega et al. 2019, Lu et al. 2009, Ho 2011, Phukerd \& Soonwera 2013, Suksathan et al. 2013, Zhao et al. 2017).

Although there are reports about the antibacterial activity of the Zingiberaceae species (El Haouari \& Rosado 2016, Jantan et al. 2008), no reports have been carried out in the 
Colombian Amazon Region and no information is available about the antiplatelet properties of EOs of $\mathrm{H}$. coronarium J. Koening.

Given the importance of the prevention and treatment of cardiovascular diseases and in order to expand the knowledge about the antibacterial activity of $\mathrm{H}$. coronarium J. Koening, the aim of this study was to evaluate the antiplatelet and antibacterial activities of EOs obtained from leaves and rhizomes of this plant.

\section{MATERIAL AND METHODS}

\section{Plant Material and essential oils (EOs) Extraction}

The plant material (leaves and rhizomes) of Hedychium coronarium J. Koening (HCL and HCR) were collected in May 2012 (wet season, winter), folio number 5-2018, from the research center MACAGUAL of the Universidad de la Amazonia (Colombia) with coordinates, North: $01^{\circ} 29^{\prime}$ 51.1" West: $75^{\circ} 39^{\prime} 35.5^{\prime \prime}$, at $254 \mathrm{~m}$ above sea level and classified taxonomically. A voucher specimen of plant (№ 9001) was deposited in the herbarium of the Universidad de la Amazonia (Colombia). Dried material of HCL and HCR (200 g) were subjected to hydro-distillation for $6 \mathrm{~h}$, using a Clevenger apparatus to afford EOs yields of 0.36\% (v/w) for HCL and $0.07 \%$ for HCR.

Moisture traces were removed by drying the EOs over anhydrous sodium sulfate $\left(\mathrm{Na}_{2} \mathrm{SO}_{4}\right)$, the EOs were collected in glass vials and kept at $4{ }^{\circ} \mathrm{C}$ until GC-MS analysis.

\section{GC-MS analysis}

The analysis of the EOs obtained from $\mathrm{HCL}$ and HCR were performed on an GC-MS (HP 5890-II GC/MS system), equipped with a detector HP 5972 (MSD), scanned in the $40-350 \mathrm{~m} / \mathrm{z}$ range, with an optimum value of the capillary voltage of $70 \mathrm{eV}$. Compounds were separated on a DB5MS capillary column $(60 \mathrm{~m} \times 0.25 \mathrm{~mm} \times 0.25$ $\mu \mathrm{m})$. The column temperature was set at $50^{\circ} \mathrm{C}$ (2 min) with an increase of $8{ }^{\circ} \mathrm{C} \mathrm{min}^{-1}$ until 325 ${ }^{\circ} \mathrm{C}$ (50 min), the carrier gas was helium at a flow of $1 \mathrm{~mL} \mathrm{~min}$.

The identities of the oil components were identified based on comparison of the linear Retention Index (RI) calculated relative to a series of $n$-alkanes (C7-C40; Sigma-Aldrich), confirmed by comparison with published RI values (Adams 2007), and via mass spectral comparison using the mass spectral library software (NIST 08 2008).

\section{Platelet Aggregation Assay}

Blood samples were obtained from volunteers donors who signed an informed consent approved by the scientific ethics committee of the Universidad de Talca (Folio number 5-2018). The samples were collected by phlebotomy in $3.2 \%$ citrate tubes, mixed and allowed to stand for $5 \mathrm{~min}$. The samples were then centrifuged at $1000 \mathrm{rpm}$ for $10 \mathrm{~min}$ to obtain a supernatant rich in platelets, which were adjusted to $2 \times 10^{5}$ platelets $/ \mu \mathrm{L}$ with platelet-depleted plasma, using a hematological counter.

The platelet aggregation was performed in vitro using a lumi-aggregometer (Mekhfi et al 2004). For this, $480 \mu \mathrm{L}$ of platelets $\left(2 \times 10^{5}\right.$ platelets $/ \mu \mathrm{L}$ ) were put in an aggregometer tube and pre-incubated with $20 \mu \mathrm{L}$ of the respective EOs $(1,0.5,0.25$ and $0.1 \mathrm{mg} / \mathrm{mL}$ ), solubilized in dimethylsulfoxide (DMSO), after 5 min of incubation, $20 \mu \mathrm{L}$ of ADP $4 \mu \mathrm{M}$ or collagen $1 \mu \mathrm{g} /$ $\mathrm{mL}$ as agonist were added to initiate the platelet aggregation. The aggregation process was followed for $6 \mathrm{~min}$, and the platelet aggregation were determined (maximal amplitude (\%)) by the software AGGRO/LINK (Chrono-Log, Havertown, PA, USA). All the measurements were performed in triplicate; DMSO (1\%) was used as negative control (100\% aggregation). 


\section{Antibacterial Activity}

Strains used were Enterococcus faecalis (ATCC 51299) and Staphylococcus aureus (ATCC 25923). Prior the assay, they were seeded in Brain heart infusion (BHI) medium, incubated at $37{ }^{\circ} \mathrm{C}$ and spiked for $24 \mathrm{~h}$ for their metabolic activation.

\section{Antibacterial Screening}

As screening the agar diffusion method was used to evaluate the antibacterial activity of the EOs (HCR and HCL). In $100 \mathrm{~mm}$ diameter plates with Mueller-Hinton agar were seeded with a 0.5 McFarland standard of each bacterium under study (per plate). Subsequently, $6 \mathrm{~mm}$ diameter paper discs impregnated with $15 \mu \mathrm{L}$ of each of the EOs (HCR and $\mathrm{HCL}$ ) were deposited on the Mueller-Hinton agar plates with the microorganisms. The agar plates were incubated at $37{ }^{\circ} \mathrm{C}$ for $24 \mathrm{~h}$ and the inhibition diameters were measured in millimeters and as a reference antibiotic was used chloramphenicol (CAF) at a concentration of $30 \mu \mathrm{g} /$ Sensi-Disc.

\section{Determination of Minimum Inhibitory Concentration (MIC) and Minimum Bactericidal Concentration (MBC) by 96 -well plate microdilution}

The MIC and MBC were determined by the microdilution test according to the recommendations of the National Committee of Clinical Laboratory Standards (NCCLS, 1999) (CLSI 1999). The assay was carried out in MuellerHinton broth, and the HCR and HCL EOs were dissolved in 1\% DMSO. The concentrations tested for each essential oil (EO) ranged from 0.02 to 48 $\mathrm{mg} / \mathrm{mL}$, bacterial suspensions were obtained by incubation at $37{ }^{\circ} \mathrm{C}$ for $12 \mathrm{~h}$ and for the assay were adjusted to $2 \times 10^{5} \mathrm{CFU} / \mathrm{mL}$. The microplates were incubated at $37^{\circ} \mathrm{C}$ for $24 \mathrm{~h}$ and the MIC was defined as the lowest concentration of the $\mathrm{EO}$ in which the microorganism does not show visible growth, determined by the absence of turbidity in the microwell. To determine the MBC, those microwells without turbidity were subcultured by seeding $10 \mu \mathrm{L}$ of the content in a plate free of microorganisms with Mueller-Hinton agar and incubated at $37^{\circ} \mathrm{C}$ for $24 \mathrm{~h}$. The $\mathrm{MBC}$ was defined as the concentration of the EO that eliminated the $99.99 \%$ of the microorganism tested. The antibiotic of reference (CAF) was used at a concentration of 0.195 to $100 \mu \mathrm{g} / \mathrm{mL}$.

\section{Statistical Analysis}

The results were analyzed statistically, comparing the results of each EO under study with the negative control (DMSO 1\%). The results were expressed as mean \pm SE, the statistical analysis t-test was used with the software SPSS 15.0 (StatisticalProduct and ServiceSolutions). $p$-value $<0.05$ were considered statistically significant.

\section{RESULTS AND DISCUSSION}

\section{Chemical Composition of HCL and HCR essential oils}

From the HCL EO were identified 19 compounds (92.9\%), with a high content of oxygenated monoterpenes (50.33\%), it was also found a 23.35 and $19.20 \%$ corresponding to monoterpene hydrocarbons and sesquiterpene hydrocarbons, respectively. A total of twelve compounds constitute the oxygenated monoterpenes group, being the 1,8-cineole (22.68\%) and $\beta$-terpineol (7.90\%) the major components, additionally, in decreasing orderwere found pinocarvone (4.45\%), myrtenol (2.00\%), cis-carveol (2.05\%) and perillyl alcohol (2.79\%), whereas the monoterpene hydrocarbons content comprise in decreasing order: $\beta$-pinene (14.78\%), $\alpha$-pinene $(7.10 \%)$ and Y-terpinene (1.47\%). Moreover, the presence of $\beta$-caryophyllene (12.95\%), $\alpha$-humulene (2.87\%), $\beta$-cis-farnesene (1.90\%) and $\beta$-guaiene (1.48\%) were present in the $19.2 \%$ of the sesquiterpene 
hydrocarbons (Table I). An EO extracted from $\mathrm{HCL}$ cultivated in Choco, Colombia, showed a similar composition to that found in this study, being the 1,8-cineole (31.5\%), $\beta$-pinene (13.7\%), terpinen-4-ol (6.0\%) and $\alpha$-pinene (3.8\%), the major constituents (Caballero-Gallardo et al. 2014).

From the HCR EO were identified 20 compounds (89.90\%), composed of a high content of monoterpene hydrocarbons (52.41\%), followed by 4 oxygenated monoterpenes (18$75 \%)$ and 5 sesquiterpenes (8.91\%). A total of five compounds constitute the monoterpene hydrocarbons group, being the tricyclene (33.46\%) and $\alpha$-pinene $(13.11 \%)$ the major components. The oxygenated monoterpenes, camphor (6.20\%), pinocarvone (5.39\%), linalool $(4.72 \%)$, the sesquiterpene caryophyllene (3.59\%) and the oxygenated sesquiterpene caryophyllene oxide (5.87\%) are also important constituents of this EO.

In $H$. coronarium, tricyclene has been reported as constituent (2.7\%) of fresh leaves EO, from Choco, Colombia (Caballero-Gallardo et al. 2014) and in lower percentage (0.04\%) in HCR EO from Eastern India (Ray et al. 2017). There are not reports about occurrence of this metabolite as major compound in HCR EO. However, metabolites as $\alpha$-pinene and linalool have also been found as important constituents of EO from HCR growing in Eastern India (Ray et al. 2017, Parida et al. 2015). Furthermore, cadinol, caryophyllene oxide, nerolidol, caryophyllene, pinocarvone, camphor, geraniol, Y-terpinene, cis- $\beta$-terpineol, $Y$-gurjunene have been found in lower quantities (< 1 and < 0.1 \%) (Ray et al. 2017), leaving in evidence that the different components varies greatly with the crop, climate and geographical position.

\section{Inhibition of platelet aggregation}

The EO obtained from HCL showed no antiplatelet activity against the aggregation induced by ADP $4 \mu M(p>0.05)$, nevertheless, when collagen $1 \mu \mathrm{g} / \mathrm{mL}$ was used as agonist, an antiaggregant activity was observed at a concentration of $0.5 \mathrm{mg} / \mathrm{mL}(p<0.05)$ and $1 \mathrm{mg} /$ $\mathrm{mL}(p<0.001)$, with a percentage of inhibition of the platelet aggregation of $30.8 \pm 1.2 \%$ and $71.7 \pm$ $2.2 \%$, respectively.

For its part, the EO extracted from HCR showed an increase in the inhibition of the platelet aggregation (using ADP $4 \mu \mathrm{M}$ as agonist) as the concentration of the EO increased, with a percentage of inhibition of the platelet aggregation of $18.3 \pm 0.9 \%$ at a concentration of $0.25 \mathrm{mg} / \mathrm{mL}$, until a $85.1 \pm 1.8 \%$ of inhibition of the platelet aggregation at a concentration of $1 \mathrm{mg} /$ $\mathrm{mL}$ (Table II). A similar and more intense effect was observed when collagen was used as agonist with a percentage of inhibition of the platelet aggregation of $48.6 \pm 1.5 \%$ at a concentration of $0.25 \mathrm{mg} / \mathrm{mL}$, until $97.2 \pm 2.1 \%$ of inhibition of platelet aggregation at a concentration of $1 \mathrm{mg} /$ $\mathrm{mL}$.

The presence of platelets within the bloodstream is crucial for the regulation of the clotting process. The HCL and HCR EOs extracted from $H$. coronarium presented different activities against the platelet aggregation induced by ADP. The ADP is considered a mild platelet agonist and is involved in the activation and platelet aggregation amplification (Murugappa \& Kunapuli 2006). The HCR was the only EO that showed antiplatelet activity against the aggregation induced by ADP, among the different compounds identify in this EO highlight the presence of $\alpha$-pinene which was the second most abundant with a percentage of $13.11 \%$ of the total compounds found in the HCR EO, which is almost twice the amount presented in the $\mathrm{HCL}$ $\mathrm{EO}$, the presence of this compound could be the 
Table I. Chemical constituents of EOs of Hedychium coronarium J. Koening leaves (HCL) and rhizomes (HCR). aretention index (RI) calculated relative to a series of $n$-alkanes.

\begin{tabular}{|c|c|c|c|c|}
\hline Compound & RI calc. & RI Lit. $^{a}$ & $\%$ in HCL essential oil & $\%$ in HCR essential oil \\
\hline Tricyclene & 916 & 921 & - & 33.46 \\
\hline$\alpha$-pinene & 939 & 932 & 7.12 & 13.11 \\
\hline$\beta$-pinene & 978 & 974 & 14.78 & - \\
\hline 1,8-cineole & 1033 & 1026 & 22.68 & - \\
\hline$\delta$-Terpinene & 1051 & 1048 & - & 2.32 \\
\hline Y-terpinene & 1056 & 1054 & 1.47 & 1.45 \\
\hline Linalool & 1102 & 1095 & - & 4.72 \\
\hline trans-pinocarveol & 1133 & 1135 & 1.39 & - \\
\hline Camphor & 1136 & 1141 & - & 6.20 \\
\hline$\beta$-terpineol & 1145 & 1140 & 7.90 & 0.93 \\
\hline Pinocarvone & 1157 & 1160 & 4.45 & 5.39 \\
\hline terpinen-4-ol & 1172 & 1174 & 1.63 & - \\
\hline$\alpha$-terpineol & 1187 & 1186 & 1.48 & - \\
\hline Myrtenol & 1189 & 1194 & 2.00 & - \\
\hline Verbenone & 1206 & 1204 & 1.78 & - \\
\hline cis-(-)-carveol & 1223 & 1226 & 2.05 & - \\
\hline Carvone & 1229 & 1239 & 1.07 & - \\
\hline Geraniol & 1256 & 1252 & 1.11 & 2.07 \\
\hline Isocarveol & 1280 & 1294 & 2.79 & - \\
\hline Carvacrol & 1295 & 1298 & - & 1.51 \\
\hline$\beta$-panasinsene & 1413 & 1381 & - & 1.42 \\
\hline trans- $\beta$-caryophyllene & 1417 & 1417 & 12.95 & - \\
\hline Caryophyllene & 1423 & 1418 & - & 3.59 \\
\hline$\beta$-cis-farnesene & 1459 & 1440 & 1.90 & 1.06 \\
\hline$\alpha$-humulene & 1461 & 1452 & 2.87 & - \\
\hline Y-gurjunene & 1476 & 1475 & - & 1.74 \\
\hline$\beta$-selinene & 1491 & 1490 & - & 1.10 \\
\hline cis- $\beta$-guaiene & 1494 & 1502 & 1.48 & - \\
\hline Nerolidol & 1546 & 1540 & - & 1.08 \\
\hline Elemol & 1552 & 1548 & - & 1.09 \\
\hline Caryophyllene oxide & 1572 & 1582 & - & 5.87 \\
\hline Apiole & 1681 & 1677 & - & 1.85 \\
\hline
\end{tabular}

${ }^{\text {a }}$ retention index (RI) calculated relative to a series of $\mathrm{n}$-alkanes. 
Table II. Percent inhibition of platelet aggregation of HCL and HCR EOs.

\begin{tabular}{|c|c|c|c|c|c|c|}
\hline & \multicolumn{5}{|c|}{ Collagen $1 \mu \mathrm{g} / \mathrm{mL}$} & \\
\hline & \multicolumn{5}{|c|}{ Inhibition ratio (\%) } & $\mathrm{IC}_{50}$ \\
\hline & DMSO 1\% & $0.1 \mathrm{mg} / \mathrm{mL}$ & $0.25 \mathrm{mg} / \mathrm{mL}$ & $0.5 \mathrm{mg} / \mathrm{mL}$ & $1 \mathrm{mg} / \mathrm{mL}$ & $\mathrm{mg} / \mathrm{mL}$ \\
\hline $\mathrm{HCL}$ & $0.2 \pm 0.1$ & $0.5 \pm 0.3$ & $0.8 \pm 0.5$ & $30.8 \pm 1.2$ * & $71.7 \pm 2.2^{\star *}$ & 0.75 \\
\hline \multirow[t]{4}{*}{$\mathrm{HCR}$} & $0.3 \pm 0.2$ & $1.2 \pm 0.8$ & $48.6 \pm 1.5$ * & $85.0 \pm 1.4$ ** & $97.2 \pm 2.1 * \star$ & 0.38 \\
\hline & \multicolumn{5}{|c|}{ ADP $4 \mu \mathrm{M}$} & \\
\hline & \multicolumn{5}{|c|}{ Inhibition ratio (\%) } & $\mathrm{IC}_{50}$ \\
\hline & DMSO 1\% & $0.1 \mathrm{mg} / \mathrm{mL}$ & $0.25 \mathrm{mg} / \mathrm{mL}$ & $0.5 \mathrm{mg} / \mathrm{mL}$ & $1 \mathrm{mg} / \mathrm{mL}$ & $\mathrm{mg} / \mathrm{mL}$ \\
\hline $\mathrm{HCL}$ & $0.3 \pm 0.1$ & $0.6 \pm 0.3$ & $0.9 \pm 0.4$ & $1.2 \pm 0.8$ & $1.9 \pm 0.9$ * & $>1$ \\
\hline HCR & $0.3 \pm 0.2$ & $0.5 \pm 0.3$ & $18.3 \pm 0.9$ * & $43.2 \pm 1.8 * \star$ & $85.1 \pm 1.8$ ** & 0.61 \\
\hline
\end{tabular}

$n=6,{ }^{*} p<0.05$ and ${ }^{* *} p<0.001$ respect to the negative control (DMSO 1\%).

responsible of the antiplatelet activity, since Yang et al. (2011), described an important antiplatelet activity of the (+)- $\alpha$-pinene purified from Angelica sinensis against the aggregation induced by ADP with an $I_{50}$ of $8.23 \mu \mathrm{g} / \mathrm{mL}$. Collagen, for its part, is important for platelet adhesion and activation, 2 major platelet receptors have been identified; the receptor GPIa/IIa ( $\alpha_{2} \beta_{1}$ integrin) that contributes to platelet adhesion and GPVI, which is responsible for intracellular signaling and platelet activation (Zhou \& Schmaier 2005). Both EOs ( $\mathrm{HCL}$ and HCR), showed an antiplatelet activity against the aggregation induced by collagen being the HCR EO the most active, this antiplatelet activity could be due to the presence of $\alpha$-pinene found in the HCL which is also one of the most abundant in the HCR EO. As in case of the agonist ADP, this compound could prevent the release of calcium from the dense granules which is one of the main events in the process of platelet activation and aggregation induced by agonist such as ADP and collagen (BernaErro et al. 2016, Ware et al. 1987), moreover, in the HCR highlighted the presence of carvacrol, which despite being in low concentration, may exert an effect enhancing the antiplatelet effect of the HCR EO against the agonist collagen.
Carvacrol is one of the main substances of EO from the herb Origanum vulgaris and has been described many activities as antimicrobial (Friedman et al. 2002), antioxidant (Alma et al. 2003) and anticarcinogenic (Friedman 2014), also the antiplatelet activity has been described; at this respect, Son et al. 2005, showed that carvacrol, extracted from T. dolabrata var. hondai presented an inhibition of platelet aggregation $\left(I C_{50}, \mu \mathrm{M}\right)$ induced by collagen of $12.6 \pm 1.3 \mu \mathrm{M}$ (Son et al. 2005). At the same time, Karkabounas et al. (2006), reported the anticarcinogenic and antiplatelet activity of carvacrol with a dependent dose-effect over the platelet aggregation by different agonists.

\section{Antibacterial Activity}

For both EOs tested, only the HCR showed antibacterial activity against E. faecalis ATCC 51299 and S. aureus ATCC 25923 with an inhibitory halo of the agar diffusion method of $10 \mathrm{~mm}$ and $14 \mathrm{~mm}$, respectively (Table III). The MIC value of the HCR EO against $E$. faecalis was $3 \mathrm{mg} / \mathrm{mL}$; meanwhile the MBC obtained was $24 \mathrm{mg} / \mathrm{mL}$. Similarly, when the same EO was evaluated against S. aureus, the MIC value was $12 \mathrm{mg} / \mathrm{mL}$ and the MBC was $24 \mathrm{mg} / \mathrm{mL}$ (Table III). Regarding to the reference 
Table III. Antibacterial activity of the HCR EO against E. faecalis and S. aureus.

\begin{tabular}{|c|c|c|c|c|}
\hline & $\begin{array}{c}\text { Enterococcus } \\
\text { faecalis ATCC 51299 }\end{array}$ & Chloramphenicol & $\begin{array}{c}\text { Staphylococcus aureus } \\
\text { ATCC 25923 }\end{array}$ & Chloramphenicol \\
\hline Inhibition halo $(\mathrm{mm})$ & 10 & 11 & 14 & 19 \\
\hline MIC $(\mathrm{mg} / \mathrm{mL})$ & 3 & $3.1 \mathrm{E}-03$ & 12 & $3.1 \mathrm{E}-03$ \\
\hline $\mathrm{MBC}(\mathrm{mg} / \mathrm{mL})$ & 24 & $5.0 \mathrm{E}-02$ & 24 & $2.5 \mathrm{E}-02$ \\
\hline
\end{tabular}

MIC: Minimum Inhibitory Concentration, MBC: Minimum Bactericidal concentration.

to the reference antibiotic, the diameter of the inhibitory halo in the agar diffusion method was for E. faecalis and S. aureus of $11 \mathrm{~mm}$ and $19 \mathrm{~mm}$, respectively. The MIC values of the antibiotic for both microorganisms were $3.125 \mu \mathrm{g} / \mathrm{mL}$ and the $M B C$ value for E. faecalis was $50 \mu \mathrm{g} / \mathrm{mL}$ and 25 $\mu \mathrm{g} / \mathrm{mL}$ for S. aureus (Table III).

Both EOs ( $\mathrm{HCL}$ and HCR) were investigated about their antibacterial activity, nevertheless, only the HCR EO showed an inhibition halo against E. faecalis and S. aureus, with MIC and $\mathrm{MBC}$ in the order of the $\mathrm{mg} / \mathrm{mL}$ (Table III); as known the biological activity of an EO could be due to the presence of a single active constituent or more probably, due to the synergistic interactions of several compounds present in it (Tajkarimi et al. 2010). Thus, the antibacterial activity of HCR EO could be attributed to their main compounds such as $\alpha$-pinene, pinocarvone, tricyclene, camphor and caryophyllene oxide, or synergistic effects between major and minor components. At this regard, Memariani et al. (2017) showed the antibacterial activity of the EO of Pistacia atlantica Desf. against the Gramnegative bacteria Helicobacter pylori; the main constituent of this essential oil was $\alpha$-pinene (93.17\%) which was indicated as the responsible of the antibacterial activity.

In this study, tricyclene was the major component of the HCR EO (33.46\%), compound that was not found in HCL EO. Several EOs containing tricyclene as the major constituent has been described with antibacterial activity, among them, EOs from Azorella spinosa
(10.81- $16.99 \%$ of tricyclene) (Jara-Bermeo et al. 2016), Cordia cylindrostachya (Ruiz \& Pav.) Roem. \& Schult. (Boraginaceae) also showed high content of tricyclene (Oza MJ \& Kulkarni YA 2017) and the EO of Cordia verbenacea D.C. (Boraginaceae), that grows in Mérida-Venezuela with $23.9 \%$ of tricyclene (Meccia et al. 2009); all these EOs showed regular or good antibacterial activity against different bacteria, which may suggest the important antibacterial activity of tricyclene.

\section{CONCLUSION}

The EO obtained from leaves of $\mathrm{H}$. coronarium J. Koening showed a predominance of oxygenated monoterpenes, followed by monoterpene hydrocarbons and sesquiterpene hydrocarbons, for its part, in the HCR EO were identified 20 compounds with a different predominance, being the monoterpene hydrocarbons the largest number of identified compounds, followed by oxygenated monoterpenes and sesquiterpenes.

When ADP and Collagen were used as agonist of the platelet aggregation, both EOs showed different behaviors, the HCL EO showed no antiplatelet activity against the aggregation induced by ADP, nevertheless, an inhibition of the platelet aggregation was observed when Collagen was used. In case of the HCR EO, an inhibition of the platelet aggregation was evidenced when both agonists were used. Among the different compounds identify in these EOs, highlight the relatively high amount of $\alpha$-pinene 
and carvacrol, from which has been described an inhibition of the platelet aggregation. The $\mathrm{HCL}$ EO showed no antibacterial activity at the concentrations used, meanwhile the HCR EO showed antibacterial activity against the Grampositive bacteria S. aureus and E. faecalis, possibly due to the high amount of Tricyclene (> $33 \%$ ) found in this fraction.

\section{Acknowledgments}

This research was funded with public resources through the FONDECYT Postdoctoral fellowship No. 3170757.

\section{REFERENCES}

ADAMS RP. 2007. Identification of Essential Oil Components by Gas Chromatography/Mass Spectrometry, $4^{\text {th }}$ ed., Allured Publ. Corp, Carol Stream, IL 456: 32-51.

ALMA MH, MAVI A, YILDIRIM A, DIGRAK M \& HIRATA T. 2003. Screening chemical composition and in vitro antioxidant and antimicrobial activities of the essential oils from Origanum syriacum l. Growing in turkey. Biol Pharm Bull 26: 1725-1729.

BERNA-ERRO A, JARDÍN I, SMANI T \& ROSADO JA. 2016. Regulation of platelet function by Orai, STIM and TRP. Adv Exp Med Biol 898: 157-181.

BHANDARY MJ, CHANDRASHEKAR KR \& KAVERIAPPA KM. 1995. Medical ethnobotany of the siddis of uttara kannada district, karnataka, india. J Ethnopharmacol 47: 149-158.

CABALLERO-GALLARDO K, PINO-BENITEZ N, PAJARO-CASTRO N, STASHENKO E \& OLIVERO-VERBEL J. 2014. Plants cultivated in Choco, Colombia, as source of repellents against Tribolium castaneum (herbst). J Asia-Pac Entomol 17: 753-759.

CLSI - CLINICAL AND LABORATORY STANDARDS INSTITUTE. 1999. Methods for determining bactericidal activity of antimicrobial agents; approved guideline M26-A. Clin Lab Stand Inst 19: 2-29.

EL HAOUARI M \& ROSADO JA, 2016. Medicinal plants with antiplatelet activity. Phytother Res 30: 1059-1071.

FRIEDMAN M. 2014. Chemistry and multibeneficial bioactivities of carvacrol (4-isopropyl-2-methylphenol), a component of essential oils produced by aromatic plants and spices. J Agric Food Chem 62: 7652-7670.
FRIEDMAN M, HENIKA PR \& MANDRELL RE. 2002. Bactericidal activities of plant essential oils and some of their isolated constituents against Campylobacter jejuni, Escherichia coli, Listeria monocytogenes, and Salmonella enterica. J Food Prot 65: 1545-1560.

HO JC. 2011. Antimicrobial, mosquito larvicidal and antioxidant properties of the leaf and rhizome of Hedychium coronarium. J Chin Chem Soc 58: 563-567.

JANTAN I, RAWEH SM, SIRAT HM, JAMIL S, MOHD YASIN YH, JALIL J \& JAMAL JA. 2008. Inhibitory effect of compounds from zingiberaceae species on human platelet aggregation. Phytomedicine 15: 306-309.

JARA-BERMEO A, PEÑAILILLO P, SAN-MARTÍN A, MALAGON O, GILARDONI G \& GUTIÉRREZ M. 2016. Chemical composition and antibacterial activity of essential oils from Azorella spinosa (Apiaceae) against wild phytopathogenic bacteria. J Chil Chem Soc 61: 3246-3249.

KARKABOUNAS S ET AL. 2006. Anticarcinogenic and antiplatelet effects of carvacrol. Exp Oncol 28: 121-125.

KUNNUMAKKARA AB, ICHIKAWA H, ANAND P, MOHANKUMAR C), HEMA PS, NAIR MS \& AGGARWAL BB. 2008. Coronarin d, a labdane diterpene, inhibits both constitutive and inducible nuclear factor-kappa b pathway activation, leading to potentiation of apoptosis, inhibition of invasion, and suppression of osteoclastogenesis. Mol Cancer Ther 7: 3306-3317.

LU Y, ZHONG C, WANG L, LU C, LI X \& WANG P. 2009. Antiinflammation activity and chemical composition of flower essential oil from Hedychium coronarium. Afr J Biotech 8: 5373-5377.

MATSUDA H, MORIKAWA T, SAKAMOTO Y, TOGUCHIDA I \& YOSHIKAWA M. 2002. Labdane-type diterpenes with inhibitory effects on increase in vascular permeability and nitric oxide production from Hedychium coronarium. Bioorg Med Chem 10: 2527-2534.

MECCIA G, ROJAS LB, VELASCO J, DÍAZ T, USUBILLAGA A, ARZOLA JC \& RAMOS S. 2009. Chemical composition and antibacterial activity of the essential oil of Cordia verbenacea from the Venezuelan Andes. Nat Prod Commun 4: 1119-1122.

MEKHFI H, EL HAOUARI M, LEGSSYER A, BNOUHAM M, AZIZ M, ATMANI F, REMMAL A \& ZIYYAT A. 2004. Platelet antiaggregant property of some moroccan medicinal plants. J Ethnopharmacol 94: 317-322.

MEMARIANI Z, SHARIFZADEH M, BOZORGI M, HAJIMAHMOODI M, FARZAEI M, GHOLAMI M, SIAVOSHI F \& SANIEE P. 2017. Protective effect of essential oil of Pistacia atlantica Desf. On peptic ulcer: Role of $\alpha$-pinene. J Tradit Chin Med 37: 57-63. 
MURUGAPPA S \& KUNAPULI S.P. 2006. The role of ADP receptors in platelet function. Front Biosci 11: 1977-1986.

NIST 08 - NATIONAL INSTITUTE OF STANDARDS AND TECHNOLOGY. 2008. Mass spectral library (NIST/ EPA/NIH), National Institute of Standards ans Technology, Gaithersburg, MD.

NORIEGA P, GUERRINI A, SACCHETTI G, GRANDINI A, ANKUASH E \& MANFREDINI S. 2019. Chemical Composition and Biological Activity of Five Essential Oils from the Ecuadorian Amazon Rain Forest. Molecules 24: 1637

OH S, JEONG IH, SHIN WS, WANG Q \& LEE S. 2006. Synthesis and biological activity of (+)-hedychilactone a and its analogs from (+)-sclareolide. Bioorg Med Chem Lett 16: 1656-1659.

OZAMJ \& KULKARNI YA. 2017. Traditional uses, phytochemistry and pharmacology of the medicinal species of the genus Cordia (Boraginaceae). J Pharm Pharmacol 69: 755-789.

PARIDA R, MOHANTY S \& NAYAK S. 2015. Chemical composition of essential oil from leaf and rhizome of micropropagated and conventionally grown Hedychium coronarium koen. From eastern india. J Essen Oil Bear Pl 18: 161-167.

PHUKERD U \& SOONWERA M. 2013. Larvicidal and pupicidal activities of essential oils from zingiberaceae plants against aedes aegypti (linn.) and culex quinquefasciatus say mosquitoes. Southeast Asian J Trop Med Public Health 44: 761-771.

PRAKASH O, RAJPUT M, KUMAR M \& PANT AK. 2010. Chemical composition and antibacterial activity of rhizome oils from Hedychium coronarium koenig and Hedychium spicatum buch-ham. J Essent Oil Bear Pl 13: 250-259.

RAY A, DASH B, SAHOO A, NASIM N, PANDA PC, PATNAIK J, GHOSH B, NAYAK S \& KAR B. 2017. Assessment of the terpenic composition of Hedychium coronarium oil from eastern india. Ind Crops Prod 97: 49-55.

SON DJ, PARK YH, KIM YM, CHUNG NH \& LEE HS. 2005. Antiplatelet activity of Thujopsis dolabrata var. hondaiderived component against platelet aggregation. J Microbiol Biotechnol 15: 425-427.

SUKSATHAN R, SOOKKHEE S, ANUNTALABHOCHAI S \& CHANSAKAOW S. 2013. Chemical composition and antibacterial activity of rhizome oils from five hedychium species. Nat Prod Commun 8: 519-522.

TAJKARIMI MM, IBRAHIM SA \& CLIVER DO. 2010. Antimicrobial herb and spice compounds in food. Food Control 21: 1199-1218.

TOGNOLINI M, BAROCELLI E, BALLABENI V, BRUNI R, BIANCHI A, CHIAVARINI M \& IMPICCIATORE M. 2006. Comparative screening of plant essential oils: Phenylpropanoid moiety as basic core for antiplatelet activity. Life Sci 78: 1419-1432.

VIEITEZ I, MACEIRAS L, JACHMANIÁN I \& ALBORÉS S. 2018. Antioxidant and antibacterial activity of different extracts from herbs obtained by maceration or supercritical technology. J Supercrit Fluids 133: 58-64.

WARE JA, SMITH M \& SALZMAN EW. 1987. Synergism of plateletaggregating agents. Role of elevation of cytoplasmic calcium. J Clin Invest 80: 267-271.

YANG NY, ZHOU GS, TANG YP, YAN H, GUO S, LIU P, DUAN JA, SONG BS \& HE ZQ. 2011. Two new $\alpha$-pinene derivatives from angelica sinensis and their anticoagulative activities. Fitoterapia 82: 692-695.

ZHAO M ET AL. 2017. Antioxidative activities of essential oils and ethanol extrations from ornamental zingiberaceae species. J Essen Oil Bear Pl 20: 215-222.

ZHOU L \& SCHMAIER AH. 2005. Platelet aggregation testing in platelet-rich plasma: Description of procedures with the aim to develop standards in the field. Am J Clin Pathol 123: 172-183.

\section{How to cite}

GUZMAN L, NERIO LS, VENTURINI W, MACIAS JPJ, DONOSO W \& FORERODORIA O. 2020. Antiplatelet and antibacterial activities of Essential Oils obtained from rhizomes and leaves of Hedychium coronarium J. Koening. An Acad BrasCienc 92: e20190615. DOI 10.1590/0001-3765202020190615.

Manuscript received on October 17, 2018;

accepted for publication on August 23, 2019

\section{LUIS GUZMAN ${ }^{1}$}

https://orcid.org/0000-0003-1552-7430

\section{LUZ S. NEIRO ${ }^{2}$}

https://orcid.org/0000-0002-0303-8069

\section{WHITNEY VENTURINI}

https://orcid.org/0000-0003-1911-6006

\section{JULYLETH P.J. MACIAS ${ }^{4}$}

https://orcid.org/0000-0002-7540-0362

\section{WENDY DONOSO 5}

https://orcid.org/0000-0003-4734-2481

\section{OSCAR FORERO-DORIA 6}

https://orcid.org/0000-0002-6770-5406

${ }^{1}$ Universidad de Talca, Departamento de Bioquímica Clínica e Inmunohematología, Facultad de Ciencias de la Salud, Avenida Lircay, s/n, Casilla 747-721, Talca, Chile 
${ }^{2}$ Universidad de la Amazonia, Programa de Química, Calle 17 Diagonal 17 Carrera 3F, Florencia, Colombia

${ }^{3}$ University of Talca, Faculty of Health Sciences, Lircay Avenue, w/no., mailbox 747-721, Talca, Chile

${ }^{4}$ Universidad Nacional de la Plata/UNLP, Department of Chemistry, Facultad de Ciencias Exactas, Instituto de Investigaciones Fisicoquímicas Teóricas y Aplicadas / INIFTA, CCT La Plata-CONICET, Casilla de Correo 16, Sucursal 4, La Plata, 1900, Argentina

${ }^{5}$ Universidad de Talca, Departamento de

Estomatología, Facultad de Ciencias de la Salud, Avenida Lircay, s/n, Casilla 747-721, Talca, Chile

${ }^{6}$ Universidad de Talca, Instituto de Química de Recursos Naturales, Avenida Lircay, s/n, Casilla 747-721, Talca, Chile

Correspondence to: Oscar Forero Doria

E-mail: oforero@utalca.cl

\section{Author contributions}

Luis Guzmán and Oscar Forero-Doria conceived, designed the experiments and wrote first draft of manuscript. Luz Stella and Julyleth Jiménez supervised the study and reviewed manuscript. Wendy Donoso contributed conducting the experiments. Whitney Venturini contributed to writing specific sections of the manuscript. All authors analyzed and interpreted data, drafted the paper, read and approved the final manuscript.

(cc) BY 